\title{
An Approach to Collection Inventory
}

All large libraries eventually face the problem of determining catalog accuracy. This paper recommends taking pilot samples of the collection to be followed by a selective inventory. The procedures and task times of the recent inventory of the Houston Public Library are included.

I IARGE ACADEMIC AND PUBLIC LIBRARIES considering an inventory should be interested in the planning and results of the inventory of the Main Library of the Houston Public Library-the decision to inventory, the procedure, the time estimates, and the results of the inventory.

The library had taken its last complete inventory in 1924 and partial inventories in 1934 and 1943. But by 1968 staff and user complaints about the accuracy of the public card catalog led the library to consider the possibility of taking the first complete inventory in fifty years.

\section{PrLot Inventory}

The first step was to define book losses more accurately by checking a random sample of the shelflist against the shelves. The collection to be inventoried consisted of 236,519 titles held in 357,350 volumes. For the sample, a loss rate of 30 percent was assumed. Sampling tables indicated 600 titles needed to be pulled at random from the shelflist. ${ }^{1}$

The sample cards were duplicated and sent to subject departments where their staff compared the shelflist cards with the titles on the shelves, marking

Mr. Clark is chief, Technical Services, Houston Public Library, Houston, Texas. the accession numbers located. Cards not matched with books initially were periodically checked again over five months. The results of the survey indicated that 41 percent \pm 3.5 percent of the volumes and approximately 35 percent of the titles in the shelflist for the Main Library were missing. While there was a backlog of book cards for volumes reported lost that had not been withdrawn from the catalog, the backlog could not explain the losses indicated by the sample inventory. The library decided to inventory the Main Library.

\section{Procedure}

The first step was to divide the collections into manageable sections for inventory and prepare a procedure. The chapter by R. E. Beck and J. R. McKinnon on the "Development of Methods and Time Standards for a Large Scale Library Inventory" was used in designing a procedure and estimating time. ${ }^{2}$

The inventory of each collection divided itself into three parts: (1) the physical inventory of the volumes on the shelf; (2) post-inventory follow-up to check volumes in circulation during inventory; and (3) withdrawing the titles from the shelflist and pulling card sets from the public catalog. In the physical inventory each book was compared with its shelflist card, checking 
the accession number. One member of the team read the call number from the book as well as title and accession number. Another staff member, holding the shelflist tray, located the correct shelflist card and wrote the year in red beside the accession numbers located. The staff member holding the book marked the book pocket and shelflist accession number with a date ("70) in red. When a shelflist could not be found for a title, the staff prepared a duplicate shelflist on a three-by-five-inch slip. Later, the cataloging staff either found or recreated the shelflist and other necessary records. Our first estimate for the time to do the shelf inventory was fifty volumes per man hour. The first inventory indicated that forty-two volumes per man hour was more realistic.

The inventory follow-up lasted for 120 days after the inventory. The staff checked volumes returning from circulation for evidence of inventory. For each returning book that missed the shelf inventory, the staff marked the book pocket with the inventory date and wrote a three-by-five-inch slip including author, title, accession number, and call number. This slip was used later to add the inventory date to the shelflist.

The last phase of the inventory was divided into three steps. The first was marking "withdrawn" on the shelflist card after the accession numbers not found in inventory, pulling the shelflist card if dead for the system, and turning up in the tray those cards dead at Main Library only. This was done at the rate of 300 per hour. These cards were revised by a cataloger at the rate of 900 cards per hour, and finally copy slips were typed for the standing shelflist cards to be used to pull cards from the public catalog.

The second step in the last phase of the inventory was to pull catalog cards from the official catalog, main public catalog, and departmental catalog. Staff members from technical service and public service joined in pulling these cards. This was done at a rate of forty cards per hour.

Finally, the cards pulled were checked for complete card sets at a rate of 1,600 cards per hour, retrieving any that were overlooked and refiling cards pulled by mistake. One unit card for each dead title was then sent to the departmental librarian to consider for replacement.

\section{ACtual InVENTORY}

The Business Technology collection was selected as the first room for inventory. It was relatively small (147 sections), and the inventory sample indicated the room had a high loss rate. A map of the room was prepared that showed shelving, the call numbers for each range, and the number of sections per range. At a staff meeting before the inventory, procedures were explained and staff members were given copies of the procedures, a room map, and their team assignments. Teams of two staff members were assigned specific portions of the shelflist. Responsibility for the teams was divided between two supervisors responsible for the teams in their respective areas. As each team completed its first assignment, a supervisor reassigned the team another portion of the shelflist. The supervisor tried to reassign a team so that it would not run into another team in the narrow aisles.

In this inventory of the Business Technology collection almost 12,000 volumes were found to be missing, representing 21 percent of the collection's titles. Two hundred volumes had errors in either call number or accession number, and fifty volumes belonging to other units were removed. Some problems with the inventory procedure were identified. Too many teams had been assigned to a supervisor. In following inventories as many as four area supervisors were used. Other changes includ- 
ed showing team leaders the ranges that they were responsible for prior to the inventory and marking inventoried shelves with white paper slips instead of turning books down. The average time for actually inventorying the books was .7 minute per volume.

Following completion of the shelf inventory, volumes returning from circulation were checked as they came back to the library. At the end of the 120-day period, a check was made to estimate the error rate of the first inventory. A random group of 622 shelflist cards of the Business Technology Room was pulled and compared with books on the shelf. Nine volumes in the sample had not been inventoried, yielding an estimated error of 1.45 percent \pm 3 percent. To confirm this, the shelves were checked a second time for the 5,200 titles that were indicated missing and only 36 titles (.05 percent) were located. Inventory reliability was judged sufficient, and the second search was dropped for inventories of other collections.

Over the next three years four other collections were inventoried. By the fall of 1972 shelf inventories were complete, but there remained a large number of cards not yet pulled from the catalogs. To complete this task each technical service unit was assigned fifteen hours per week for card pulling, and public service units later also made commitments. The inventory of the
Main Library was completed in July 1973.

\section{Results and Discussion}

What did the inventory accomplish? Removed from the public catalog were cards for 47,514 missing titles, representing 20 percent of the titles in the Main Library catalog. Before the inventory two out of every five cards referred the user to books that were not available. The ratio was probably higher since a large percent of requests are for material published in the last five years, and a large portion of the lost titles fell in this category. The losses by collection are listed in Table 1 . The catalogs of the inventoried rooms prior to the project contained 236,519 titles, and the holdings were 357,350 volumes.

The inventory was done without the employment of a special inventory team and, consequently, at the expense of current operations. A better approach would have been one in which a fulltime team of three were responsible for a selective inventory. The pilot inventory overestimated volume losses by 10 percent and titles by 15 percent. The error appeared to be the result of using many individuals unfamiliar with the shelflist to take the sample. However, the later survey in Business Technology indicated that much more precise results could be obtained by assigning it to a single staff member who was familiar with the project and shelflist.

TABLE 1

InVentory Results at Houston Public LibraryMAIN LIBRARY

\begin{tabular}{|c|c|c|c|c|c|}
\hline & $\begin{array}{c}\text { Missing } \\
\text { Titles }\end{array}$ & & $\begin{array}{c}\text { Missing } \\
\text { Volumes }\end{array}$ & & \\
\hline Business Technology Room & 5,273 & & 11,918 & & \\
\hline Fine Arts Room & 3,627 & & 10,502 & & \\
\hline Children's Room & 5,222 & & 10,629 & & \\
\hline Literature \& Biography & 11,933 & & 38,122 & & \\
\hline Remainder $000-500 \mathrm{~s}$ & 21,459 & & 40,030 & & \\
\hline Total & $\frac{47,514}{236,519}$ & $=\begin{array}{l}20 \text { percent of } \\
\text { titles missing }\end{array}$ & $\frac{111,201}{357,350}$ & $=$ & $\begin{array}{l}31.1 \text { percent of } \\
\text { volumes missing }\end{array}$ \\
\hline
\end{tabular}


With random sampling, a library that is uncertain of the accuracy of its public catalog can with a small expenditure of staff time obtain a reliable estimate of its catalog accuracy. Such a survey is certainly justified, considering the cost of staff time in inventory. The error rate that justifies an inventory is a matter of judgment, with libraries suggesting rates that vary from 1 percent to 5 percent. $^{3}$ However, the interruption of normal processing or the cost of ad- ditional staff to inventory a large collection, I believe, makes a loss rate of 10 percent a more realistic guideline. A pilot inventory can be used to identify those collections that have an unacceptable discrepancy between the titles that the catalog shows and those actually available. Using the pilot inventory as a guide to the collections in need of inventory, libraries will find selective inventories a more effective approach than general inventories.

\section{ReFerences}

1. R. Gene Brown and Lawrence L. Vance, Sampling Tables for Estimating Error Rates or Other Proportions (Berkeley: Public Accounting Research Project, Institute of Business and Economic Research, University of California, 1961).

2. Barton R. Burkhalter, ed., Case Studies in Systems Analysis in a University Library
(Metuchen, N.J.: Scarecrow, 1968), p.4875.

3. Irene A. Braden, "Pilot Inventory of Library Holdings," ALA Bulletin 62:1129-31 (Oct. 1968); Pamela Bluh, "A Study of an Inventory," Library Resources \& Technical Services 13:367-71 (Summer 1969). 